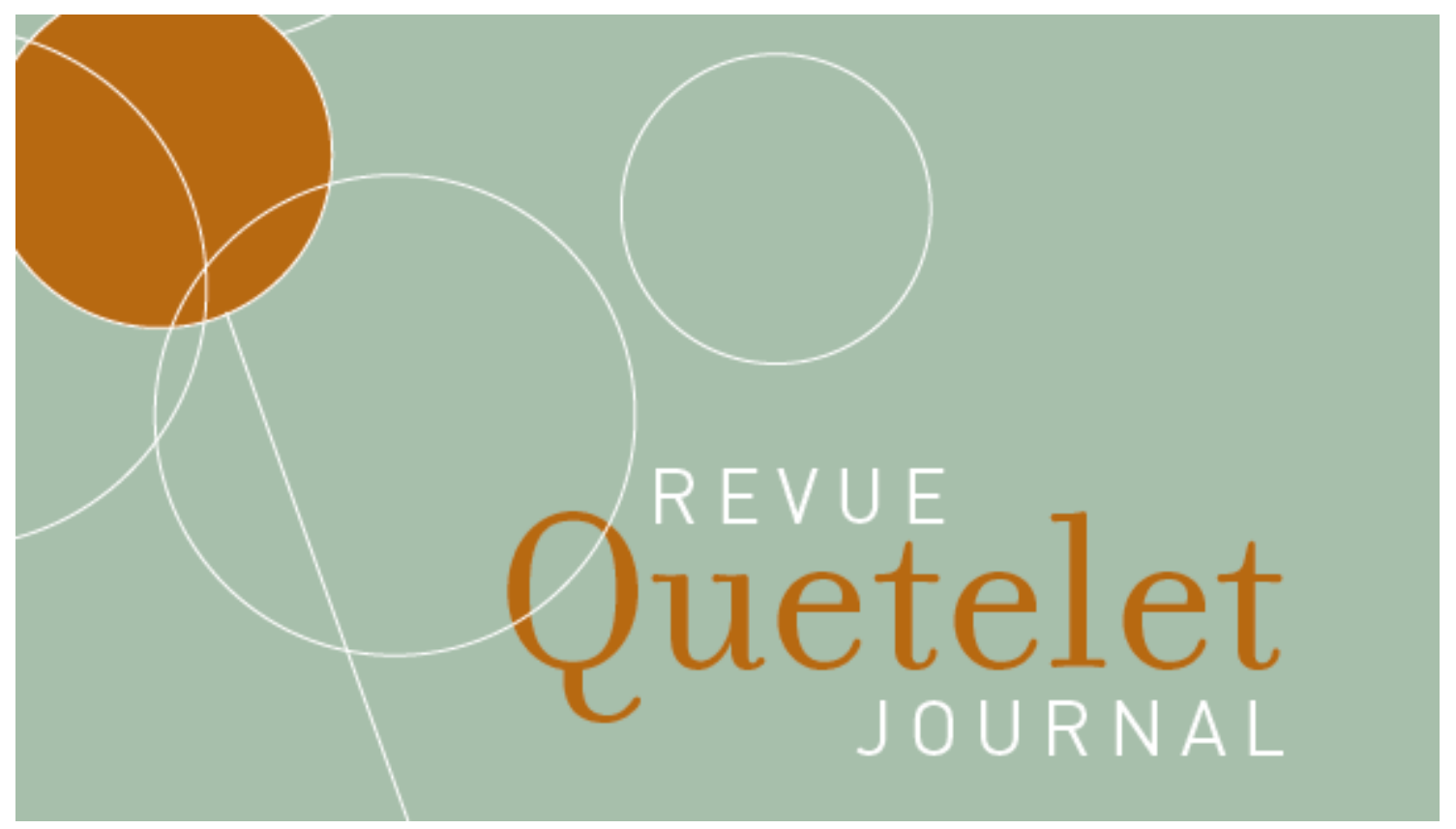

Vol. 7, n 1, avril 2019, pp. 71-99

DOI : 10.14428/rqj2019.07.01.03

ISSN: 2593-9157

\title{
Refugees' trajectories in Switzerland: Impact of residence permits on labour market integration
}

Anne-Laure Bertrand

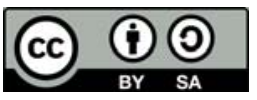

(C)2019 Anne-Laure Bertrand

This work is licensed under a Creative Commons Attribution-NonCommercial 4.0 International License. You can share, adapt the material for non-commercial purposes provided that you give appropriate credit and indicate if changes were made. For details see https://creativecommons.org/licenses/by-sa/4.0/

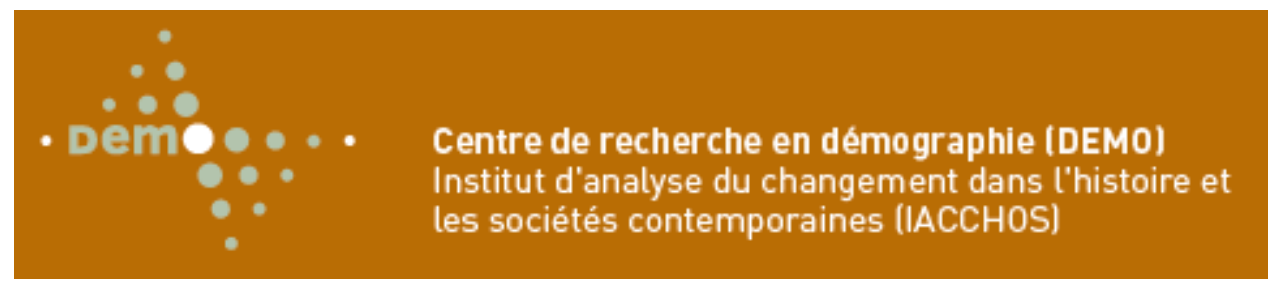





\title{
Refugees' trajectories in Switzerland: Impact of residence permits on labour market integration
}

\author{
ANNe-LAURE BERTRAND ${ }^{1}$
}

\begin{abstract}
Résumé
Les parcours de vie des populations réfugiées dans les pays européens dépendent fortement des différents statuts et permis de séjour qui leur sont attribués. Prenant le cas de la Suisse, cet article vise à montrer l'impact du cadre légal sur les chances d'intégration des réfugiés au marché du travail. Le terme "réfugié» désigne ici l'ensemble des individus venus en Suisse pour demander asile, ceci quelle que soit l'issue de la procédure - et non uniquement ceux ayant obtenu le statut tel que défini par la Convention de Genève de 1951. Dans cette étude, le suivi longitudinal des individus est rendu possible par l'appariement de plusieurs registres de population. D'un point de vue descriptif, des outils d'analyse de séquences permettent de visualiser les trajectoires des réfugiés à partir de leur arrivée dans le pays - tant en terme de permis de séjour que de participation au marché du travail. Des modèles de survie montrent ensuite qu'il existe un parallèle entre statut administratif et statut économique, l'accès à des permis de séjour stables accroissant significativement les chances d'intégration au marché du travail. Il en résulte un cumul des désavantages pour ceux qui restent durant de longues années avec les permis les plus précaires (requérants d'asile et personnes admises à titre provisoire). En résumé, si la vulnérabilité économique des réfugiés a été soulignée par de nombreuses études, cet article montre qu'au sein de la population réfugiée, la législation des pays d'accueil crée une hiérarchie supplémentaire, basée sur les permis de séjour, qui creuse encore les inégalités.
\end{abstract}

Mots-clés

Réfugiés, permis de séjour, législation, statut administratif, intégration au marché du travail, analyse longitudinale, registres de population, Suisse.

\section{Abstract \\ Life course trajectories of refugee populations in European countries highly depend on the various statuses and residence permits that are assigned to them. Taking the}

1. Institute of Demography and Socioeconomics, University of Geneva, and Laboratory for the Understanding of Social Processes, University of Neuchâtel. 
case study of Switzerland, this article aims at showing the impact of the legal framework on refugees' chances of labour market integration. The term «refugee» here refers to all the individuals who came to Switzerland seeking asylum, no matter the outcome of the asylum procedure - and not only to those who obtained the status as defined by the 1951 Geneva Convention. In this study, the longitudinal follow-up of the individuals is made possible by the matching of data from several population registers. From a descriptive point of view, sequence analysis allows the visualization of refugees' trajectories from their arrival in the country - in terms of both residence permits and of labour market participation. Survival analysis models then show the concordance between the administrative status and the economic status, the access to more stable permits increasing significantly the chances of labour market integration. As a consequence, those who remain for many years with the most precarious permits (asylum seekers and provisionally admitted persons) go through a process of cumulative disadvantage. Although the economic vulnerability of refugees has been highlighted previously, this paper shows that within the refugee population, the host countries' legislation creates an additional hierarchy, based on the residence permits, that further widens inequalities.

\section{Keywords}

Refugees, residence permits, legislation, administrative status, labour market integration, longitudinal analysis, population registers, Switzerland.

\section{Introduction}

Legislation shapes individuals' life trajectories. This is particularly true for refugees who come to Europe to find shelter, since their administrative status and residence permit determine their rights and opportunities to integrate into the host society. Taking the case study of Switzerland - one of the European countries with the highest number of refugees per inhabitant -, this study focuses on the issue of the impact of Swiss legislation on refugees' life courses from the moment they arrive in the country. To do so, I draw a parallel between the residence permit system and its actual effects on refugees' chances to integrate into the labour market. In this paper, the term «refugee» is used to refer to all the individuals who came to Switzerland seeking asylum no matter the outcome of the asylum procedure, and not only to those who obtained the status as defined by the 1951 Geneva Convention. Whenever needed, the latter are specifically referred to as «recognized refugees». The choice of a «broad» definition ensures that the concept of refugee is not reduced to the sole meaning it has in international law, which, as Zetter (2014, p. 11) points out, 
does not reflect the complexity of persecution of victims of forced migration and the wide variety of reasons that drive people to flee.

The structure of this paper is as follows: taking the «refugee gap» as a starting point, I go further into the subdivision of the refugees' administrative statuses and focus on the issue of precarious legal statuses. The next section describes the legislation relating to the residence permit system faced by refugees in Switzerland, which leads to the research question and hypotheses. Drawing on examples from previous studies, the «methods» section begins with a discussion about the challenge of conducting quantitative longitudinal research on the refugee population. It is followed by a presentation of the data and of the indicator I use to capture labour market integration. Trajectories of residence permits and labour market integration are then both examined through sequence analysis. Finally, the impact of residence permits on labour market integration opportunities is evaluated using survival models and discussed.

\section{Background}

\section{The «refugee gap»}

Structural integration, including in particular integration into the labour market, has long been (and still is) considered as a key indicator of a broader integration process (Gordon, 1964). The economic vulnerability of the refugee population compared to other immigrant groups and to the natives - the so-called «refugee gap» - has been assessed by many researchers (see Ott (2013) for an extensive literature review on the subject). Nowadays, it remains a burning topic as illustrated by the recent work of Newman et al. (2018) who edited a special issue devoted to the employment of refugees, by the study of Bakker et al. (2017) on the refugee gap they observe in the Netherlands, and by the proposition of Bansak et al. (2018) to use an algorithm that allocates refugees to specific resettlement locations in order to improve their chances of employment within the host country. The question of labour market integration does not only concern the refugees who crossed a border to seek for protection, but also the internally displaced persons who face as well a longterm effect of cumulative disadvantage due to their forced displacement (Ivlevs, Veliziotis, 2018). 
However, difficulties in integrating into the labour market of the host country cannot be explained solely by having migrated for asylum reasons. In fact, the filing of an asylum application marks the beginning of a complex administrative process made up of transitions between multiple statuses and residence permits. The precariousness of some of these statuses and permits creates an additional hierarchy within the refugee group itself. This hierarchy, inherent to the various statuses and permits, leads to inequalities in opportunities for integration, particularly with regard to access to the labour market - even if, of course, it also impacts other life areas, such as possibilities concerning family reunification, housing, or mobility (both within and outside the host country). All these dimensions are linked and affect the integration of refugees into the society.

\section{Precarious legal statuses}

The paramount role of legislation and immigration policies on the «legal construction of illegality» has been highlighted in various contexts. For example, Calavita (1998) analysed the social and economic exclusion of immigrants in Spain, De Genova (2002) focussed on the U.S.-Mexico border, and Vickstrom (2014) took the case of Senegalese migrants in France, Italy, and Spain. Overcoming the binary distinction between the «documented» and the «undocumented», Menjívar (2006) proposed the concept of «liminal legality» to shed light on the grey area of in-between situations faced by Salvadoran and Guatemalan immigrants who were granted a «temporary protected status» (TPS) in the U.S. This is related to the notion of "permanent temporariness» brought by Bailey et al. (2002) who also analysed how the TPS affected the Salvadorans' daily life. Following the same idea, Goldring et al. (2009, p. 243) called for the use of the term "precarious legal status» in order to «draw attention to the systemic, legal and normalized production of a range of precarious, or less than full, im/migration statuses» that they observe in the Canadian context. In turn, Kofman (2002, p. 1'051) used the term «civic stratification» to describe the complex system developed by European states that «differentiate access to civil, economic and social rights depending on mode of entry and legal status».

In line with these authors, this paper aims to demonstrate that even within the «legal immigrant group», there is a wide scale of statuses that determine an immigrant's position in the host society - and therefore the chances he or she has to integrate into this society. Goldring et al. (2009) proposed a vast review of the Canadian legislation and policy on a variety 
of statuses (sponsored family members, refugee claimants, temporary workers, visitors, students, and persons with no status), emphasizing that no hierarchy of status should be deduced from the fact that they use the term "gradation» to describe this range of situation. Conversely, this article focuses solely on the refugee group and explores the subdivision of their administrative statuses. By doing so, I intend to highlight the actual administrative hierarchy that is produced by Switzerland's legislation, and the impact that this hierarchy has on refugees' labour market integration in the long run.

Concrete implications for public policies are at stake. Any revision of the laws regarding refugees' statuses and residence permits can have immediate consequences on the individuals' lives and their chances to integrate into the society. In Switzerland, if efforts are made on encouraging refugees' labour market participation, the latest legislative changes have shown that when it comes to the residence permits, Switzerland is rather taking the opposite direction (Bertrand, 2017). An example of the ongoing public policies lies in the will of the Swiss authorities to shorten the asylum procedure. Although such a measure can be seen as an improvement, the State Secretariat for Migration (SEM) is in fact giving the priority to cases leading to a negative decision (mainly Dublin cases and dismissed applicants), while the requests of people who have a high probability to obtain some form of protection (refugee status or provisional admission) come after ${ }^{2}$. For the latter, this leads to long years of waiting with an asylum seeker status. On that matter, according to the Federal Council, «obstacles to the [asylum seekers'] labour market integration must be maintained until the asylum decision» (Conseil fédéral, 2016, p. 35, our translation).

\section{Seeking asylum in Switzeland: The residence permit system}

Switzerland's legislation regarding residence permits is divided into the Asylum Act (AsylA) and the Federal Act on Foreign Nationals (FNA). The AsylA aims at regulating the asylum procedure and legal statuses of refugees in Switzerland, while the FNA addresses the questions of foreigners' stays and integration. Table 1 summarizes the various possible statuses (and, for Switzerland, the residence permits). A comparison is made with

2. See, for example, the SEM statement of 24.09.2015 (www.sem.admin.ch/sem/ fr/home/aktuell/news/2015/2015-09-24.html) and the Federal Council and Federal Office for Migration report (Conseil fédéral, ODM, 2014, p. 9). 
the statuses given by the European legislation (Bader, 2018, p. 72). I provide a detailed explanation of the Swiss asylum procedure and permit changes in Bertrand (2017, pp. 13-19) but, in summary, four main residence permits can be granted to persons who have come to Switzerland to seek asylum:

- The N permit is the asylum seekers' permit. It concerns people whose asylum request is being examined by the authorities (Art. 42 AsylA). At the end of the asylum procedure, asylum seekers are either forced to leave Swiss territory (if the asylum request is rejected), or allowed to stay in the country (if the request is accepted or, in case of rejection, if there are legal reasons to let them stay) - and therefore are granted another status and residence permit.

- The F permit is a provisional admission. It allows temporary stay on the territory for rejected asylum seekers that Switzerland cannot deport (either because sending them back would put their lives at risk or merely because of practical reasons, Art. 83 FNA). Each year, the renewal of their authorization to stay is submitted to evaluation (individuals facing therefore the same situation of "permanent temporariness" depicted by Bailey et al. (2002)). Part of the F permit holders are recognized refugees to whom asylum was denied. Such status applies to those «who qualify for the refugee status according to the Geneva Convention but not in the sense of the Swiss AsylA» (Bader, 2018, p. 72), for instance, when their reasons to seek for asylum arose after or because they fled their country (Art. 53 and 54 AsylA).

- The B permit is a residence permit that can be given for several reasons: 1) to recognized refugees who were granted asylum (Art. 60 AsylA); 2) because of humanitarian reasons, for $\mathrm{N}$ and $\mathrm{F}$ permit holders who can prove that they are «highly integrated» in the Swiss society (Art. 14 al.2 AsylA and Art.84 al.5 FNA); 3) for other reasons such as marriage with a Swiss citizen or with a B/C permit holder.

- The $C$ permit is a settlement permit that is usually given to «well integrated» individuals after 5 to 10 years of residence with a B permit (Art. 34 FNA).

It should be pointed out that $B$ and $C$ permits are also the main residence permits that are given to «non-refugee foreigners» who have come to Switzerland for work or family reasons. This explains why B and C permit holders with a refugee background tend to become «statistically invisible» as soon as they receive such residence permits, as they often fade into the vast majority of $\mathrm{B}$ and $\mathrm{C}$ permit holders who are not concerned by forced migration (Pecoraro, 2005; Widmer, 2005; Piguet, Besson, 2005). 
TABLE 1 Statuses and residence permits according to Switzerland's legislation and their equivalent in the European legislation

\begin{tabular}{|c|c|c|c|c|c|}
\hline \multirow{2}{*}{$\begin{array}{c}\text { Equivalent in the EU } \\
\text { legislation } \\
\text { Status }\end{array}$} & \multicolumn{5}{|c|}{ Switzerland's legislation (AsylA and FNA) } \\
\hline & Status & $\begin{array}{l}\text { Resi- } \\
\text { dence } \\
\text { permit }\end{array}$ & $\begin{array}{c}\text { Access to labour } \\
\text { market }\end{array}$ & $\begin{array}{l}\text { Right to family } \\
\text { reunification }\end{array}$ & Mobility \\
\hline $\begin{array}{l}\text { Person being a sub- } \\
\text { ject of a pending ap- } \\
\text { plication }\end{array}$ & Asylum seeker & $\mathbf{N}$ & Restricted & None & $\begin{array}{l}\text { None (or with } \\
\text { minor excep- } \\
\text { tions) }\end{array}$ \\
\hline $\begin{array}{l}\text { Person granted sub- } \\
\text { sidiary protection sta- } \\
\text { tus }\end{array}$ & $\begin{array}{l}\text { Provisionally admit- } \\
\text { ted person }\end{array}$ & \multirow[t]{2}{*}{$\mathbf{F}$} & $\begin{array}{l}\text { Partially } \\
\text { restricted }\end{array}$ & Restricted & Restricted \\
\hline (No equivalent) & $\begin{array}{l}\text { Provisionally admit- } \\
\text { ted refugee }\end{array}$ & & No restriction & Restricted & $\begin{array}{l}\text { Partially } \\
\text { restricted }\end{array}$ \\
\hline $\begin{array}{l}\text { Person granted refu- } \\
\text { gee status }\end{array}$ & Recognized refugee & \multirow{3}{*}{ B } & No restriction & $\begin{array}{l}\text { Partially } \\
\text { restricted }\end{array}$ & $\begin{array}{l}\text { Partially } \\
\text { restricted }\end{array}$ \\
\hline $\begin{array}{l}\text { Person granted au- } \\
\text { thorization to stay for } \\
\text { humanitarian reasons }\end{array}$ & $\begin{array}{l}\text { Person granted resi- } \\
\text { dence permit for hu- } \\
\text { manitarian reasons }\end{array}$ & & No restriction & $\begin{array}{l}\text { Partially } \\
\text { restricted }\end{array}$ & $\begin{array}{l}\text { Partially } \\
\text { restricted }\end{array}$ \\
\hline $\begin{array}{l}\text { Person granted au- } \\
\text { thorization to stay }\end{array}$ & $\begin{array}{l}\text { Person granted resi- } \\
\text { dence permit (for } \\
\text { other reasons) }\end{array}$ & & No restriction & $\begin{array}{l}\text { Partially } \\
\text { restricted }\end{array}$ & $\begin{array}{l}\text { Partially } \\
\text { restricted }\end{array}$ \\
\hline $\begin{array}{l}\text { Person granted per- } \\
\text { manent residence } \\
\text { permit }\end{array}$ & $\begin{array}{l}\text { Person granted set- } \\
\text { tlement permit }\end{array}$ & C & No restriction & No restriction & No restriction \\
\hline
\end{tabular}

In addition to the aforementioned information, Table 1 gives an indication of the restrictions that are imposed on each category regarding access to labour market, mobility, and right to family reunification (based on the AsylA and the FNA). To mention only a few examples, asylum seekers ( $\mathrm{N}$ permit) face a waiting period of 3 to 6 months before being allowed to work. Then, several requirements need to be met, including approval of the authorities to whom the employer must first prove that «no suitable domestic employees or citizens of states with which an agreement on the free movement of workers has been concluded can be found for the job» (Art. 21 FNA). What is more, in order to offset administrative costs generated by the asylum procedure, a «special charge» is taken directly from the asylum seeker's wage $\left(10 \%\right.$ of earned income, up to $15^{\prime} 000$ Swiss francs - Art. 86 AsylA). All of this results in troublesome administrative procedures that can discourage the employers. However, asylum seekers are not the only ones facing obstacles to their integration. The authorities' agreement is also required for provisionally admitted persons (F permit), although Article 21 FNA does not apply to them, and they also have to pay the «special charge». Although most of the F permit holders eventually settle in Switzerland (Efionayi-Mäder, Ruedin, 2014), the term «provisionally» tends to scare potential employers who are afraid 
to invest in someone who can be deported back at any time (UNHCR, $2014)^{3}$. Thus, both $\mathrm{N}$ and $\mathrm{F}$ permit holders fit the definition of "precarious legal status» proposed by Goldring et al. (2009).

This paper's aim is to understand the impact of the residence permits on refugees' integration into the labour market. My hypothesis is that the more stable the residence permit, the better the chances of labour market integration. Schematically, I expect to observe the following hierarchy amongst the residence permits: $\mathrm{N}<\mathrm{F}<\mathrm{B}<\mathrm{C}$, going from the most precarious one to the most stable one. The underlying mechanism could be both a direct consequence of inequalities between the various residence permits in the access to the labour market, as well as an indirect consequence of the obstacles that $\mathrm{N}$ and $\mathrm{F}$ permit holders can experience in other domains.

I assume that the residence permit influences the labour market integration - and not the other way round, as can be found, for example, in Vickstrom (2014), who analysed the role of labour market participation on the risk to fall into «irregularity»- because for the refugees, residence permit changes depend on the asylum procedure and length of stay, and not on labour market participation. One exception is with people granted a B permit for humanitarian reasons, since such status means that the individual is already «well integrated» in Swiss society in general and the labour market in particular (Art. 84 FNA). Other criteria are also considered, such as the family situation and the possibility of a return to the home country, but the economic situation plays a central role in the decision. Hence, for this group, we face a case of reverse causality (labour market integration leading to the acquiring of a B permit for humanitarian reasons).

\section{Methods}

\section{Studying the trajectories}

Two types of trajectories stand at the heart of this paper: trajectories of residence permits, and trajectories of labour market integration. So far, the question of the link between the socio-economic integration of refu-

3. Recognizing that the «special charge» was an obstacle to the labour market integration of N and F permit holders, the Swiss authorities repealed it on January 1st, 2018. 
gees and their residence status and/or the time spent in the asylum procedure has been addressed in several cross-sectional analyses. The study of Spadarotto et al. (2014) is a first example, as it focussed on the labour market participation of about 2'700 recognized refugees, provisionally admitted persons and persons granted residence permit for humanitarian reasons who arrived in Switzerland between 1997 and 20004. Likewise, Bakker et al. (2014) found significant discrepancies in the economic situation of refugees depending on their status (the comparison being made between temporary status, permanent status, and Dutch citizenship for the four largest groups of refugees in the Netherlands). For his part, in the Belgian context, Wets (2014) concluded that legal status (recognized refugees, people with subsidiary protection, and asylum seekers) only played a minor role in explaining the chances of being employed.

Complementing the cross-sectional analysis by Wets (2014), Herman and Rea (2014) conducted a longitudinal analysis of the recognized refugees "career paths» in Belgium, proposing a typology of socio-economic integration trajectories. However, as the individuals' career trajectories were only followed from the moment they received the refugee status (and not from the lodging of the asylum application), this study could not capture the effect of the permit changes or the time spent in asylum procedure on the types of trajectories. This last point has been answered by Hainmueller et al. (2016), who showed the negative impact on employment chances of the length of time spent with an asylum seeker status. Their study examined a selected population within the refugee group: individuals who applied for asylum in Switzerland (between 1994 and 2004) and who were granted subsidiary protection - not the refugee status within 5 years. This selection explains why the authors did not address the question of residence permits. Finally, Torstensson et al. (1997) showed the possibilities offered by asylum registers to analyse the administrative trajectories of Turkish and Somali refugees in Sweden and in Switzerland. Their study did not, however, include the issue of the labour market trajectories. Conversely, Kogan (2004) did not focus on administrative trajectories (nor did she concentrate exclusively on the refugee group), but she analysed the discrepancies between career sequences of immigrants vs. natives in Germany and in the UK.

4. The fact that this study was conducted on behalf of the State Secretariat for Migration shows that the Swiss authorities have a strong interest in understanding underlying mechanisms of refugees' labour market integration. 
Conducting quantitative longitudinal research on such population groups represents a real methodological challenge that explains the relative scarcity of such studies. Researchers often face a lack of data enabling a longrun follow-up of the refugee population (Liu et al., 2016, pp. 746-747). In addition, comparing the situation between different countries with different legal systems that keep evolving over time can be extremely difficult, as noted by Beauchemin (2015, p. 24) and Liu et al. $(2016$, p. 764) in their analyses of the Migrations between Africa and Europe (MAFE) and Mexican Migration Project (MMP) databases. Yet, whenever possible, adopting a longitudinal perspective is essential when it comes to analysing individuals' pathways to integration.

Accordingly, the following analyses are organized in two steps. First, relying on sequence analysis graphical tools (Gabadinho et al., 2011), I describe the refugees' trajectories of residence permits on the one hand, and their labour market integration on the other hand. Second, I study the causal relation between residence permits and chances to integrate into the labour market using discrete time survival models.

\section{Data}

Data used in this study - hereafter: the «Refugee database» - consist of matched population registers and allow a longitudinal follow-up of the individuals (Steiner, Wanner, 2015; Wanner et al., 2016). Precisely, the record linkage between the Automatic Registration System of Persons (for $\mathrm{N}$ and $\mathrm{F}$ permit holders), the Central Register of Foreign Nationals (for B and C permit holders, as well as other permits concerning, for example, family members of diplomats), and the Population and Households Statistics (covering, since 2010, both the permanent and the nonpermanent resident population of Switzerland) allows following the refugee population over time. These registers include administrative information such as citizenship, residence permit, date of birth, sex, marital status, and duration of stay. Yet, the Refugee database does not include information about the households.

These registers are supplemented by data from the Central Compensation Office (CCO), the Confederation's agency in charge of the 1st pillar social insurances. The CCO data provides information on each individual's annual wage (i.e., the income from an employed or self-employed activity). Both sources combined constitute therefore a unique opportunity to investigate the labour market integration process at the individual level. Such possibilities offered by the use of public statistics are even more important in a quantitative perspective, since conducting a specific 
survey would raise significant issues (including the question of how to reach the refugee population, not to mention the very low response rate expected from individuals who may be very suspicious of any questionnaire that might remind them of the asylum procedure).

Of course, there are drawbacks to this approach: the administrative purpose of public statistics entails the lack of some information. One can only regret the absence of indication of hourly wage (a lack that will have an impact on the labour market integration indicator), educational level, number of children, health status, housing type and, last but not least, about the outcome of the asylum procedure. This last point explains why, for example, when a change from $\mathrm{N}$ permit to $\mathrm{B}$ permit occurs, it is not possible to know whether such a transition is a consequence of the recognition of the refugee status or if it is due to a marriage with a Swiss citizen or with a holder of a B/C permit (even if this last scenario certainly applies to fewer individuals). Likewise, a change from $\mathrm{F}$ permit to $\mathrm{B}$ permit can also be the consequence of a marriage, although it is more likely that the residence permit was granted for humanitarian reasons (Art. 84 $F N A$ ). Note that a change from an $\mathrm{N}$ permit to a $\mathrm{B}$ permit for humanitarian reasons can theoretically also occur (Art. 14 AsylA), but such cases are rare.

The refugee population includes all the individuals who came to Switzerland since 2000 and who were still in the country for at least a year between 2010 and 2013. This selection criterion is entailed by the impossibility to compile databases for refugees who left Switzerland before 2010. It should also be noted that refugees who had access to Swiss citizenship before 2010 cannot be identified in the registers.

Furthermore, as this study focusses on labour market integration trajectories, only the individuals who were aged between 18 and 49 when they arrived in Switzerland are selected. This population is therefore composed of 53'562 individuals, of whom $69 \%$ are men - a population that will be referred as to "the 2000-2013 arrival cohorts», as opposed to a subgroup named «the 2000-2004 arrival cohorts», which only includes refugees who can be followed for at least ten years after their arrival to Switzerland. The «2000-2004 arrival cohorts» contains 10'248 individuals ( $57 \%$ men).

Appendix 1 shows the frequencies for each nationality (or nationality of origin for refugees who became Swiss citizens) by sex for the 2000-2013 arrival cohorts. Main countries of origin are Eritrea, Sri Lanka, Afghanistan, Somalia, China and Tibet, Turkey, Iraq, Syria, and Nigeria, which together represent more than $60 \%$ of the refugees. 


\section{Indicator of labour market integration}

Given the lack of any indication about their employment status, the only information available to measure the refugees' labour market integration is their annual wage (i.e. the income from an employed or self-employed activity). Hence the question: "What is the minimum wage one should earn to be considered properly integrated in the labour market?» The Swiss Federal Statistical Office (FSO/OFS) approach for the at-risk-ofpoverty level is to fix the threshold at $50 \%$ of the median of equivalized disposable income of households (OFS, 2016). Indeed, it is a poverty indicator, measured at the households' level. This study extends this approach to create a labour market integration indicator, measured at the individuals' level, by taking the threshold of $50 \%$ of the annual median wage in Switzerland. This median wage is calculated amongst all men living in Switzerland (not only amongst the refugee population) who constitute the reference group. I do so in order to reduce the bias induced by the fact that the hourly wage is unknown, as in Switzerland full-time work is much more common for men than it is for women (Bläuer Herrmann, Murier, 2016). Indeed, the threshold varies over time, from 32'402 Swiss francs in 2000 to 35'631 Swiss francs in 2013. Although somewhat imperfect, this indicator still represents a solution for approaching labour market integration through registers data.

\section{Results}

\section{Trajectories amongst the residence permits}

Graphical representations of individual state sequences are used to describe the refugees' trajectories of residence permits. As the information pertaining to the refugees' residence permit is available only at the end of each year, the granularity is annual. Several «states» can be listed, four of them consisting of the most common cases: the N, F, B, and C permits. The remaining categories are labelled «OTH» for other types of permits, 
«CH» for Swiss nationality, «UD» for undocumented workers and «ABR» when the person lives abroad 5 .

FigURE 1 Longitudinal follow-up, individuals' trajectories according to their residence permit (or status), 2000-2004 arrival cohorts

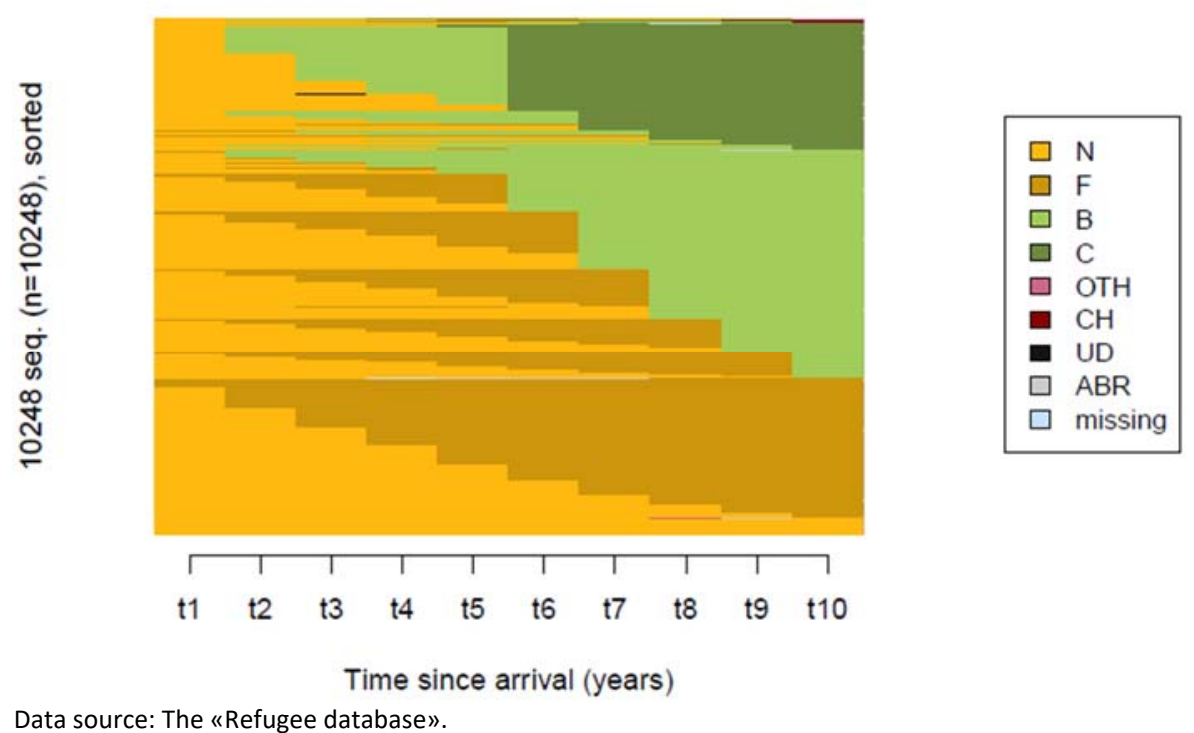

Figure 1 shows the trajectories of the 2000-2004 arrival cohorts from the end of the first year of their arrival in Switzerland $(t 1)$ until their tenth year in the country $(t 10)$. Here, sequences are sorted so the refugees are grouped together according to the last permit they held. Four colours prevail: light orange for asylum seekers ( $\mathrm{N}$ permit), dark orange for provisional admission (F permit), light green for B permit holders and dark green for $\mathrm{C}$ permit holders. Amongst them, orange colours dominate, which means that the first 10 years of presence in Switzerland are mostly spent with the most precarious residence permits. In fact, nearly a third

5. The «OTH» category includes residence permits for members of the families of intergovernmental organizations/foreign representations, permits for foreign nationals who are resident in a foreign border zone, and short-term residence permits. The category «undocumented worker» refers to persons who contribute to social insurance (a contribution deducted from the person's income) although they are not registered as living in Switzerland during the year under observation. Finally, it should be mentioned that the «ABR» category can, in a few cases, indicate that the individual is deceased (although most of the time it simply means that he/she emigrated). 
of the $10^{\prime} 248$ refugees still held a precarious permit after 10 years - mostly an F permit (27.3\%), while 3.4\% (350 individuals) remained with an asylum seeker permit in $t 10$. In time, the proportion of precarious permits decreased to be replaced by more stable permits: $43.8 \%$ end up with a B permit in $t 10$, and $24.7 \%$ with a $\mathrm{C}$ permit. It should be remembered that here only the refugees who stayed in the country for at least 10 years are examined ${ }^{6}$, while those who were deported back to their country of origin or to another country in the meantime are not included in Figure 1 (see Appendix 2 for a broader view of the sequences for the 2000-2013 arrival cohorts).

Although, as mentioned, the information about the outcome of the asylum procedure is not available in the data, several hypotheses can be made based on Figure 1. In fact, until 2014, the recognized refugees were eligible to a $\mathrm{C}$ permit 5 years after they applied for asylum (Art. 60 AsylA). For the others, the 5-year delay starts to run only after they obtain a $B$ permit (Art. $34 \mathrm{FNA}^{7}$. As a result, I assume that amongst the individuals who hold a $C$ permit in $t 10$, many are recognized refugees. Following the same idea, I also assume that most of the individuals who hold a B permit in $t 10$ obtained this B permit for humanitarian reasons - an assumption supported by the fact that many of them experience several years with a provisional admission (F permit). Again, this cannot be verified, recalling that a change of residence permit can also be the consequence of a marriage with a Swiss citizen or with a holder of a B/C permit. Still, as we will see, this link between the status (recognized refugees vs. persons granted $B$ permit for humanitarian reasons) and the residence permit in $t 10$ (C permit vs. B permit) is of great importance to understand the mechanisms we will observe later ${ }^{8}$.

6. At least 11 years for the 2000 arrival cohort since these individuals had to still be present in Switzerland at the end of 2010 or afterwards.

7. Since February 1, 2014, Art. 34 FNA applies for everyone. The C permit is therefore no longer made accessible faster for recognized refugees - which is another example of the ongoing policy of restricting access to the most stable permits.

8. For an in-depth analysis of residence permit trajectories (including transition rates, trajectories patterns, and their explanatory factors), see Bertrand (2017, pp. 152183). 
Impact of the residence permit on the chances

to integrate into the labour market

Figure 2 shows the trajectories of men and women of the 2000-2004 arrival cohorts according to the labour market integration indicator. Dark blue is used every year the individual is considered integrated in the labour market. Again, sequences are ordered by status from the end of the trajectory. What immediately stands out is the gap between men and women, as, after 10 years of stay in Switzerland, 53\% of men are integrated in the labour market while it is only the case for $19 \%$ of women. Another prevailing fact is the considerable impact of time in the integration process, as after every additional year spent in Switzerland more refugees are incorporated into the labour market according to the indicator. Finally, Figure 2 indicates that while some individuals tend to go backand-forth between statuses, the main trend is to remain integrated for many years once the threshold is reached. It should be pointed out that this does not mean refugees remain in the same job from one year to the next, but merely that they manage to keep their annual wage above the threshold of $50 \%$ of the median wage - even when a change of job occurs.

FIGURE 2 Longitudinal follow-up, individuals' trajectories according to the labour market integration indicator by sex, 2000-2004 arrival cohorts

Men $(57.2 \%)$

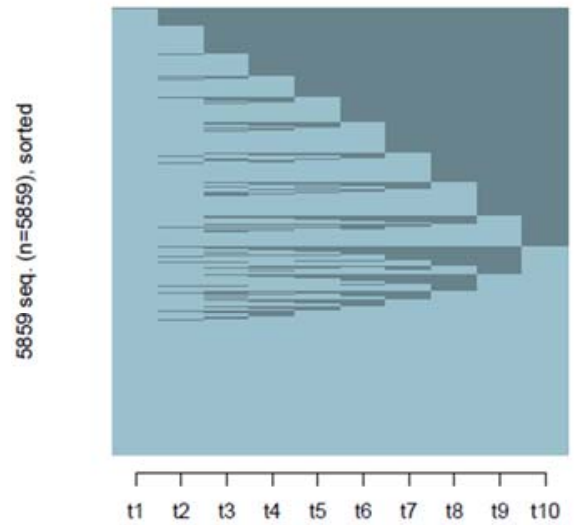

Women $(42.8 \%)$

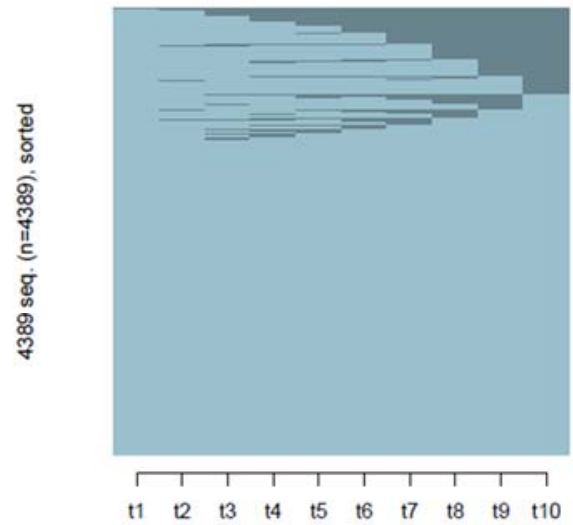


A first way of addressing the research question is to compare the labour market integration rates by residence permit in $t 10$. By doing so, the complexity of the residence permit trajectories is partially ruled out, each individual being defined only by the permit he/she holds 10 years after arriving in Switzerland. Figures 3 and 4 respectively show the labour market integration trajectories by residence permit in $t 10$ for men and women.

FIGURE 3 Longitudinal follow-up, men's trajectories according to the labour market integration indicator by residence permit in $t 10,2000-2004$ arrival cohorts

$\mathrm{N}(4.6 \%)$

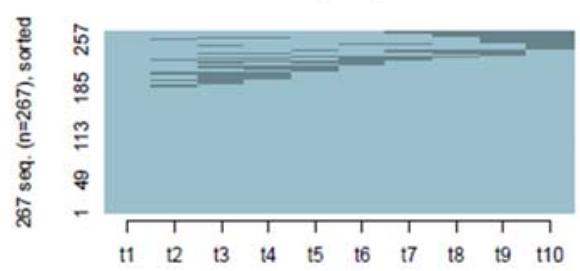

B $(45.4 \%)$

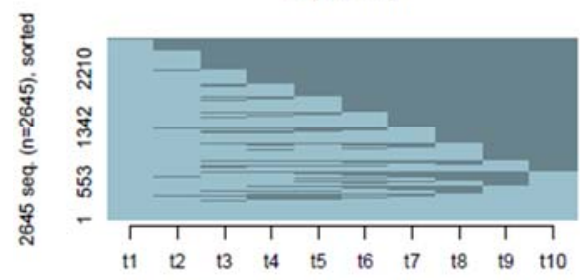

$\mathrm{CH}(0.5 \%)$

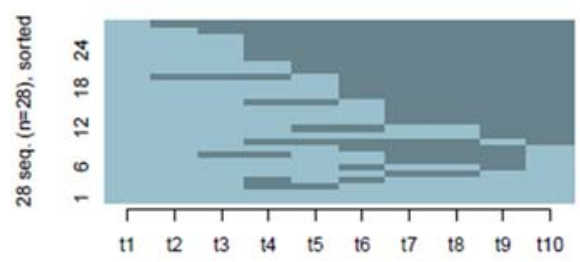

Data source: The «Refugee database».

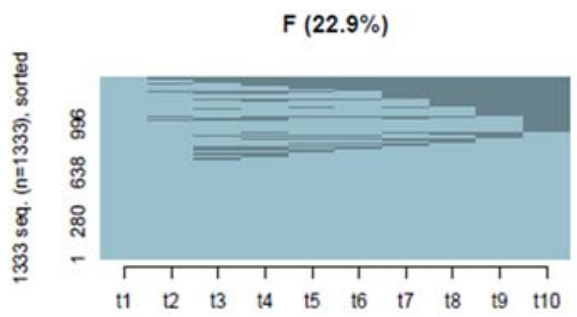

C $(26.7 \%)$

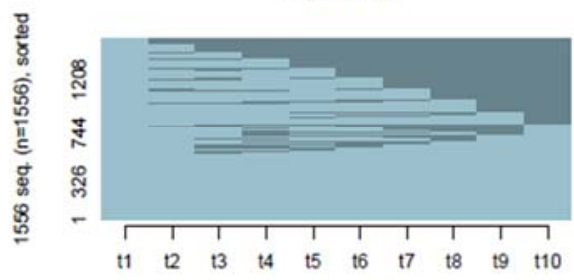

$\square<50 \%$ median wage

$\square>50 \%$ median wage 
FIgURE 4 Longitudinal follow-up, women's trajectories according to the labour market integration indicator by residence permit in $t 10,2000-2004$ arrival cohorts

$\mathrm{N}(1.9 \%)$

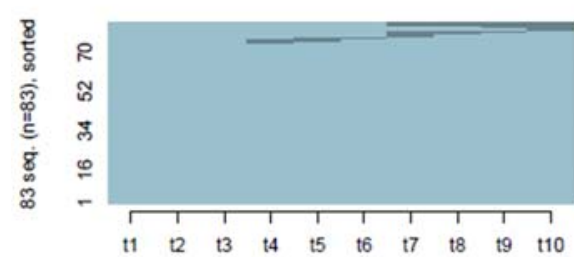

B $(42.3 \%)$

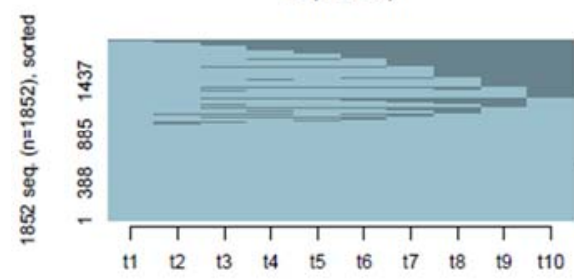

$\mathrm{CH}(0.3 \%)$

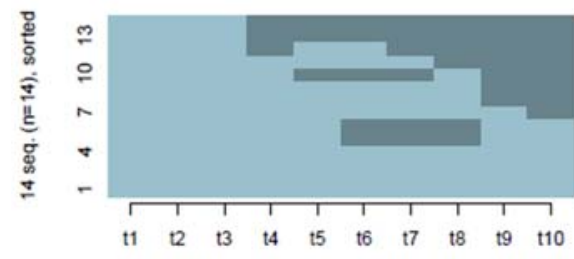

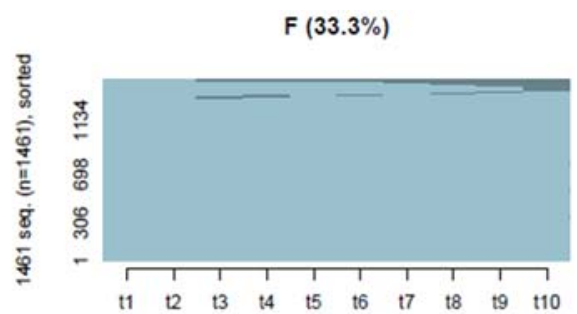

C $(22.2 \%)$

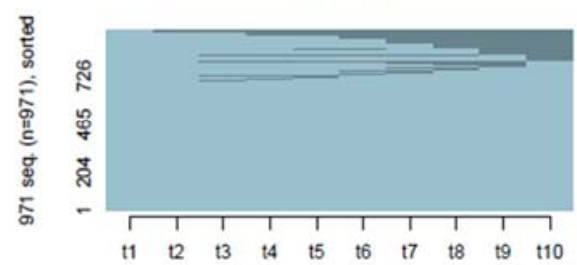

$\square<50 \%$ median wage $>50 \%$ median wage

Data source: The «Refugee database».

Looking at the situation after 10 years spent in Switzerland, Figure 3 shows that $9 \%$ of men who are still in the asylum procedure (N permit) are considered integrated in the labour market. Holders of provisional admission (F permit) are in turn 29\%, while B and C permit holders are respectively $73 \%$ and $47 \%$ to be considered as integrated. Similar trends can be observed amongst women, though with much lower labour market integration rates: Barely $4 \%$ of women holding an N permit after 10 years in Switzerland are considered integrated, while the rate is $5 \%$ for the $\mathrm{F}$ permit holders. Relatively higher rates are found amongst the B permit 
holders (31\% of women integrated in the labour market) and the $\mathrm{C}$ permit holders $(17 \%)^{9}$.

These results for $\mathrm{B}$ and $\mathrm{C}$ permit holders are unexpected, since the hypothesis was that the $C$ permit would lead to better chances of integration. However, this apparent gap between $\mathrm{B}$ and $\mathrm{C}$ permit holders hides, in fact, the gap between recognized refugees and persons granted $B$ permit for humanitarian reasons mentioned above: there is a strong selection effect at stake. This interpretation is consistent with the results obtained by Spadarotto et al. (2014).

All in all, these descriptive results already show the impact of the residence permits on labour market integration. The wide gap between the integration rates of those who still hold a precarious permit (N/F) after 10 years spent in Switzerland and those who obtained more stable permits $(B / C)$ in the meantime reflects the cumulative disadvantage process that the former suffer in the long run. This result stands when controlling for structural variables (nationality, marital status, age, and canton of residence) in logistic regression models (Bertrand, 2017, pp. 227-235).

We now turn to discrete-time survival models to grasp the dynamics of the residence permit effect on the chances to integrate the labour market (i.e., income in excess of $50 \%$ of the median wage), controlling for possible confounding variables such as nationality or length of stay. Due to the gender discrepancies observed above, models are separated for men and women. Survival analysis allows modelling the probability that a given event - here «a first integration into the labour market» - occurs over time. Discrete-time logistic regression is run on a person-period data file to express the chance that the event occurs depending on various explanatory factors (either fixed or time-varying), and given the fact that it did not occur before. Here, it is not necessary to observe individuals over an equal period of time, hence the inclusion in this analysis of the 53'562 refugees of the 2000-2013 arrival cohorts. Independent variables of the model are residence permit, length of stay, age, marital status, nationality, and canton of residence. Table 2 shows the results of the residence permit variable for men and women, while controlling for the other variables. Appendix 3 displays the full model.

9. Amongst the individuals who obtained the Swiss nationality, the rate in $t 10$ is $68 \%$ for men and $57 \%$ for women. However, due to the small numbers in both groups (n $=28$ and $\mathrm{n}=14$ ), I prefer to avoid commenting these results. Note that Figures 3 and 4 do not show the trajectories of the 38 individuals ( 30 men and 8 women) who hold another type of permit or are undocumented in $t 10$. 
TABLE 2 Odds ratios of the residence permit variable to explain the occurrence of the event "first integration into the labour market», discrete time survival models, 2000-2013 arrival cohorts

\begin{tabular}{|c|c|c|}
\hline Residence permit (ref. $=\mathrm{N}$ ) & Men & Women \\
\hline $\mathrm{F}$ & $1.481 * * *$ & 0.930 \\
\hline $\mathrm{B}$ & $1.630 * * *$ & $2.019 * * *$ \\
\hline $\mathrm{C}$ & $1.858 * * *$ & $1.403^{* *}$ \\
\hline $\mathrm{CH}$ & 1.579 & 1.720 \\
\hline OTH/UD/missing & 0.566 & 2.222 \\
\hline Observations (person-year) & $132^{\prime} 742$ & $89^{\prime} 145$ \\
\hline \multicolumn{3}{|c|}{$\begin{array}{l}\text { Controlled for: Length of stay, age, marital status, nationality, canton of resi } \\
\text { dence. }\end{array}$} \\
\hline \multicolumn{3}{|c|}{$\begin{array}{l}\text { Statistical significance: }{ }^{\circ} p<0.1 ;{ }^{*} p<0.05 ; * * p<0.01 ; * * * p<0.001 \\
\text { Data source: The «Refugee database». }\end{array}$} \\
\hline
\end{tabular}

Results of the residence permit variable must be interpreted carefully due to its inherent chronology. Not only is it of ordinal nature (as permits can be ranked from the most precarious to the most stable), but also obtaining a «better» permit is most of the time an irreversible event (for example, a refugee who has a $\mathrm{C}$ permit in $t$ will not revert to $\mathrm{N}$ permit in $t+1$ ). In the survival analysis framework this has consequences, because once the «first integration into the labour market» event has occurred, individuals are no longer part of the at-risk population (they are censored). Indeed, some asylum seekers manage to integrate into the labour market despite their precarious status. However, even if these persons subsequently get an F, B, or C permit, they will not be included in the odds ratio calculation of these categories as they would no longer be at risk of experiencing the event. The same reasoning applies at each «level» of the residence permit. Thus, to take an example from Table 2, one should not interpret the odds ratio of the male $\mathrm{C}$ permit holders as a sign that their chances to integrate into the labour market are multiplied by 1.9 compared to those of the asylum seekers ( $\mathrm{N}$ permit). In fact, this should be understood as the chances to integrate with a $\mathrm{C}$ permit for the individuals who did not experience the event with a more precarious permit, compared to the chances an asylum seeker at risk during the same period would have had. Therefore, each of the odds ratios must be interpreted as the residence permit effect on labour market integration chances considering that integration did not «occur» with a more precarious permit. 
Amongst men, the odds ratios of $\mathrm{F}, \mathrm{B}$, and $\mathrm{C}$ permits gradually increase ${ }^{10}$. This gradation not only follows the hypothesis concerning the hierarchy of $\mathrm{N}, \mathrm{F}, \mathrm{B}$, and $\mathrm{C}$ permits for the chances of labour market integration, but most of all means that for the individuals who find it the hardest to integrate into the labour market, the most vulnerable persons, accessing a more stable permit makes their endeavour easier to achieve. To use an analogy, the residence permit hierarchy can be seen as a «net» with an increasingly tighter mesh: the transition to a more stable permit increases the probability of labour market integration for refugees who have so far fallen through the cracks.

Amongst women, other trends are observed. For them, the F permit does not seem to improve the chances to integrate into the labour market compared to the N permit. However, holders of a B permit distinguish themselves significantly. An hypothesis to explain the apparent lag between $\mathrm{N} / \mathrm{F}$ and $\mathrm{B}$ permits amongst women is that the labour market integration indicator fails, by construction, to account for undeclared work. Yet, it is possible that women holders of an N/F permit find themselves in such a situation, for example if they cumulate multiple small jobs in the domestic economy sector - especially if the employers try to avoid the administrative burden encountered when hiring N/F permit holders. In turn, it is much easier to officially employ someone once the $\mathrm{B}$ permit is obtained. Therefore, if undeclared work amongst N/F permit holders could have been taken into account, a smaller difference would probably have been observed amongst women between N, F, and B permit holders. More surprising is the result for the $C$ permit holders, as it appears that they have fewer chances than the B permit holders to integrate into the labour market. Nevertheless, we should consider the at-risk population: amongst the $\mathrm{C}$ permit holders, only those who did not experience the event with a more precarious permit remain at this point - constituting a selected population. Moreover, the fact that individuals who are not in the labour force «by choice» (for example to stay at home and take care of children)

10. The results for $\mathrm{F}, \mathrm{B}$, and $\mathrm{C}$ permits are significant compared to the reference category ( $\mathrm{N}$ permit) but also from one another (as checked by permuting the reference category). As mentioned earlier, the $\mathrm{OTH} / \mathrm{UD} /$ missing category will not be discussed as it covers many situations and concerns only few cases. As for those who obtained Swiss nationality, the small number of cases probably explains why the results are mitigated and non-significant both for men and women. The reason is that most naturalized individuals experience the event (and therefore are censored) before being granted citizenship. 
cannot be distinguished from individuals who are unemployed but looking for a job perhaps explains why results are more ambiguous for women.

Apart from the impact of the residence permit, the analyses show the importance of other factors on the chances to integrate into the labour market (see Appendix 3). The length of stay is indeed a key determinant of the integration process ${ }^{11}$. Being married (which can be a proxy for having to take care of children) is a factor of exclusion for women, while, for men, marriage increases the chances of integration into the labour market. Finally, nationality appears as a major determinant of labour market integration, although further analyses would be needed to explain whether inequalities are due to social network, educational level, or if they are the result of employers' discrimination towards certain communities.

\section{Conclusion}

To sum up, results show that residence permits and labour market participation are closely tied, a more stable permit generally increasing the chances to integrate into the labour market. In other words, the economic status matches the administrative status. The economic vulnerability of the refugee population - the so-called «refugee gap» - has been already well documented. By digging deeper into the administrative categorization of the individuals, this paper shows that within the refugee population, the host countries' legislation creates an additional hierarchy, based on the residence permits, that further widens the inequalities. To come back to the words of Goldring et al. (2009) and Menjívar (2006), individuals who hold precarious residence permits (or «less than full immigration statuses») find themselves in this legal «grey area» of in-between situations where they are granted the right to be present in the host country,

\footnotetext{
11. Not surprisingly, the chances of being considered integrated in the labour market are extremely low at the beginning of the stay in Switzerland, but they increase with the length of stay (and therefore with the risk exposure). Then, the apparent «decline» that we observe after 8 or 9 years of stay could be the conjunction of two factors: the first would be that of a certain «demotivation» of individuals who would still not have managed, after many years, to find a place on the labour market and who would then give up. The second would consist of a selection effect that would result in those «most apt» to find a job doing so during the first decade of their stay (which would lead to censoring since they would already have experienced the event), while those whose profile is less «attractive» for employers would remain in the population at risk until the end of the 14 years of observation.
} 
but with limited integration opportunities. As a consequence, those who live many years with the asylum seekers status ( $\mathrm{N}$ permit) or as provisionally admitted persons ( $\mathrm{F}$ permit) go through a process of cumulative disadvantage.

The residence permit alone does not explain all the inequalities in the participation to the labour market. Nevertheless, as it is a factor of vulnerability that is shaped by legislation, practical implications are at stake in terms of public policies to improve the integration of the refugee population into the labour market (and thus a broader integration into the society). Concrete measures include simplifying the criteria for granting the most stable permits as well as improving the rights of the most precarious ones (in particular on the subjects of labour market, family reunification, housing, and mobility). However, while the Swiss authorities are currently taking action to foster the integration of recognized refugees and provisionally admitted persons into the labour market, they are at the same time restricting access to the most stable residence permits. This article demonstrates the paradox of such a policy.

\section{Acknowledgements}

This research was supported by the NCCR - On the Move funded by the Swiss National Science Foundation and is based on the data gathered for the project «Intégration structurelle et déqualification de la population réfugiée en Suisse» (Wanner et al., 2016), a study funded by the State Secretariat for Migration (SEM). I warmly thank all those who took care of data extraction and matching, in particular Philippe Wanner, Ilka Steiner, and Andreas Perret (NCCR - On the Move), Christoph Freymond (FSO), Alex Pavlovic (CCO), and Pierre Fontaine (SECO). I am also very grateful towards Gilbert Ritschard and Philippe Wanner for supervising my PhD dissertation on which this article is based and which will be published in 2020 by Seismo Books under the title «Dans la jungle des permis de séjour. Parcours administratifs et intégration professionnelle des réfugiés en Suisse», towards the reviewers and the editors for their helpful comments, and towards William Doehler, Marie-Hélène Giostra, and Mark D’Arcy for proofreading this text. 


\section{References}

BADER D. (2018), «Who Ought to Stay? Asylum Policy and Protest Culture in Switzerland», S. Rosenberger, V. Stern, N. Merhaut (eds), Protest Movements in Asylum and Deportation, Cham, Springer Open (IMISCOE Research Series), pp. 69-88, https://doi. org/10.1007/978-3-319-74696-8_4.

Bailey A. J., Wright R. A., Mountz A., Miyares I. M. (2002), «(Re)Producing Salvadoran Transnational Geographies", Annals of the Association of American Geographers, 92 (1), pp. 125-144, https://doi.org/10.1111/1467-8306.00283.

Bakker L., Dagevos J., Engbersen G. (2014), «The Importance of Resources and Security in the Socio-Economic Integration of Refugees. A Study on the Impact of Length of Stay in Asylum Accommodation and Residence Status on Socio-Economic Integration for the Four Largest Refugee Groups in the Netherlands", Journal of International Migration and Integration, 15, pp.431-448, https://doi.org/10.1007/s12134013-0296-2.

BAKKer L., DAgevos J., Engbersen G. (2017), «Explaining the Refugee Gap: A Longitudinal Study on Labour Market Participation of Refugees in the Netherlands", Journal of Ethnic and Migration Studies, 43 (11), pp. 1'775-1'791, https://doi.org/10.1080/ 1369183x.2016.1251835.

Bansak K., Ferwerda J., Hainmueller J., Dillon A., Hangartner D., lawrence D., WeinSTEIN J. (2018), «Improving Refugee Integration through Data-Driven Algorithmic Assignment», Science, 359 (6'373), pp. 325-329, https://doi.org/10.1126/science. aao4408.

BeAuchemin C. (2015), «Migration between Africa and Europe (MAFE): Advantages and Limitations of a Multi-Site Survey Design ", Population, 70 (1), pp. 13-38, https:// doi.org/10.1007/978-3-319-69569-3_2.

BertRAND A.-L. (2017), Réfugiés en Suisse : trajectoires d'asile et intégration professionnelle, Genève, Thèse SdS 77, Faculté des sciences de la société, Université de Genève, $313 \mathrm{p}$.

Bläuer Herrmann A., Murier T. (2016), Les mères sur le marché du travail, Neuchâtel, Office fédéral de la statistique (OFS), $12 \mathrm{p}$.

Calavita K. (1998), "Immigration, Law, and Marginalization in a Global Economy: Notes from Spain», Law \& Society Review, 32 (3), pp. 529-566, https://doi.org/10. 2307/827756.

Conseil fédéral, ODM (2014), Rapport du Conseil fédéral en réponse au postulat du groupe libéral-radical du 24 septembre 2013 : Asile. Statistique des autorisations de séjour pour cas de rigueur, Berne, 14 p., https://doi.org/10.1163/2214-8264_ dutchpamphlets-va0-va02035.

Conseil fédéral (2016), Admission provisoire et personnes à protéger : analyse et possibilités d'action, Berne, $59 \mathrm{p}$. 
De Genova N. P. (2002), "Migrant 'Illegality' and Deportability in Everyday Life», Annual Review of Anthropology, 31, pp. 419-447, https://doi.org/10.1146/annurev. anthro.31.040402.085432.

EFIONAYI-Mäder D., RUEDIN D. (2014), Aufenthaltsverläufe vorläufig Aufgenommener in der Schweiz, Neuchâtel, Forum suisse pour l'étude des migrations et de la population (SFM), $56 \mathrm{p}$.

Gabadinho A., Ritschard G., Müller N. S., Studer M. (2011), «Analyzing and Visualizing State Sequences in R with TraMineR», Journal of Statistical Software, 40 (4), pp. 1-37, https://doi.org/10.18637/jss.v040.i04.

Goldring L., Berinstein C., Bernhard J. K. (2009), «Institutionalizing Precarious Migratory Status in Canada», Citizenship Studies, 13 (3), pp. 239-265, https://doi.org/10. 1080/13621020902850643.

GoRdon M. M. (1964), Assimilation in American Life: The Role of Race, Religion and National Origins, New York, Oxford University Press, 276 p.

Hainmueller J., Hangartner D., Lawrence D. (2016), «When Lives Are Put on Hold: Lengthy Asylum Processes Decrease Employment Among Refugees», Science Advances, 2, pp. 1-7, https://doi.org/10.1126/sciadv.1600432.

Herman B., Rea A. (2014), "Longitudinal Analysis», A. ReA, J. WeTs (eds), The Long and Winding Road to Employment: An Analysis of the Labour Market Careers of Asylum Seekers and Refugees in Belgium, Gent, Academia Press, pp. 109-146.

IVlevs A., Veliziotis M. (2018), «Beyond Conflict: Long-Term Labour Market Integration of Internally Displaced Persons in Post-Socialist Countries», Journal of Vocational Behavior, 105, pp. 131-146, https://doi.org/10.1016/j.jvb.2017.12.003.

KogaN I. (2004), «Labour Market Careers of Immigrants in Germany and the United Kingdom», Journal of International Migration and Integration, 5 (4), pp. 417-447, https://doi.org/10.1007/s12134-004-1022-x.

Kofman E. (2002), «Contemporary European Migrations, Civic Stratification and Citizenship», Political Geography, 21, pp. 1'035-1'054, https://doi.org/10.1016/s09626298(02)00085-9.

Liu M.-M., Creighton M. J., Riosmena F., Baizán P. (2016), «Prospects for the Comparative Study of International Migration Using Quasi-Longitudinal Micro-Data», Demographic Research, 35 (26), pp. 745-782, https://doi.org/10.4054/demres.2016. 35.26 .

Menjívar C. (2006), «Liminal Legality: Salvadoran and Guatemalan Immigrants' Lives in the United States», American Journal of Sociology, 111 (4), pp. 999-1'037, https:// doi.org/10.1086/499509.

Newman A., Bimrose J., Nielsen I., Zacher H. (2018), "Vocational Behavior of Refugees: How do Refugees Seek Employment, Overcome Work-related Challenges, and Navigate Their Careers?», Journal of Vocational Behavior, 105, pp. 1-5, https://doi. org/10.1016/j.jvb.2018.01.007. 
OFS (2016), Situation économique et sociale de la population : panorama, Neuchâtel, Office fédéral de la statistique (OFS), $14 \mathrm{p}$.

Oтт E. (2013), The Labour Market Integration of Resettled Refugees, Genève, United Nations High Commissioner for Refugees (UNHCR), 64 p., https://doi.org/10.1093/ law:epil/9780199231690/e530.

Piguet E., Besson R. (2005), "L'emploi indépendant des personnes d'origine étrangère», W. HAUG, P. WANNER (eds), Migrants et marché du travail : compétences et insertion professionnelle des personnes d'origine étrangère en Suisse, Neuchâtel, Office fédéral de la statistique (OFS), pp. 111-147, https://doi.org/10.1787/888933313583.

Pecoraro M. (2005), "Les migrants hautement qualifiés», W. HAUG, P. WANNER (eds), Migrants et marché du travail : compétences et insertion professionnelle des personnes d'origine étrangère en Suisse, Neuchâtel, Office fédéral de la statistique (OFS), pp. 71-109, https://doi.org/10.1787/888933160552.

Spadarotto C., Bieberschulte M., Walker K., Morlok M., Oswald A. (2014), Erwerbsbeteiligung von anerkannten Flüchtlingen und vorläufig Aufgenommenen auf dem Schweizer Arbeitsmarkt, Zurich/Basel, KEK-CDC/B,S,S., 141 p.

Steiner I., WANner P. (2015), Towards a New Data Set for The Analysis of Migration and Integration in Switzerland, On the Move Working Paper, $22 \mathrm{p}$.

Torstensson T., IsAKsson K., Cotter S., Heiniger M. (1997), Swiss-Swedish Joint Study on Cohort-Based Asylum Statistics, Luxembourg, Eurostat Working Paper on Population and Social Conditions, $69 \mathrm{p}$.

UNHCR (2014), Arbeitsmarktintegration: Die Sicht der Flüchtlinge und vorläufig Aufgenommenen in der Schweiz, Genève, Bureau du HCR pour la Suisse et le Liechtenstein, $94 \mathrm{p}$.

Vickstrom E. (2014), "Pathways into Irregular Status Among Senegalese Migrants in Europe», International Migration Review, 48 (4), pp. 1'062-1'099, https://doi.org/ 10.1111/imre.12154.

Wanner P., Bertrand A.-L., Steiner I. (2016), Intégration structurelle et déqualification de la population réfugiée en Suisse, Genève, Institut de démographie et socioéconomie (IDESO), $96 \mathrm{p}$.

Wets J. (2014), "Multivariate Analysis», A. REA, J. WeTS (eds), The Long and Winding Road to Employment: An Analysis of the Labour Market Careers of Asylum Seekers and Refugees in Belgium, Gent, Academia Press, pp. 81-107.

WIDMER L. (2005), "Chômage et populations étrangères», W. HAUG, P. WANNER (eds), Migrants et marché du travail : compétences et insertion professionnelle des personnes d'origine étrangère en Suisse, Neuchâtel, Office fédéral de la statistique (OFS), pp. 39-70, https://doi.org/10.2307/20079131.

ZetTer R. (2014), Protection des migrants forcés : État des lieux des concepts, défis et nouvelles pistes, Berne, Commission fédérale pour les questions de migration (CFM), 102 p., https://doi.org/10.4000/books.cirac.351. 
Appendix 1: Nationalities by sex, 2000-2013 arrival cohorts

\begin{tabular}{|c|c|c|c|c|}
\hline & \multicolumn{2}{|c|}{ Men } & \multicolumn{2}{|c|}{ Women } \\
\hline & $\mathrm{N}$ & $\%$ & $\mathrm{~N}$ & $\%$ \\
\hline Afghanistan & $2^{\prime} 499$ & 6.80 & 724 & 4.30 \\
\hline Algeria & 837 & 2.28 & 49 & 0.29 \\
\hline Angola & 276 & 0.75 & 365 & 2.17 \\
\hline Armenia & 108 & 0.29 & 95 & 0.56 \\
\hline Bosnia and Herzegovina & 402 & 1.09 & 507 & 3.01 \\
\hline Cameroon & 126 & 0.34 & 142 & 0.84 \\
\hline China and Tibet & $1^{\prime} 925$ & 5.24 & $1^{\prime} 181$ & 7.02 \\
\hline Côte d'Ivoire & 254 & 0.69 & 85 & 0.50 \\
\hline Democratic Republic of Congo & 400 & 1.09 & 629 & 3.74 \\
\hline Eritrea & 5’086 & 13.85 & $3^{\prime} 734$ & 22.18 \\
\hline Ethiopia & 487 & 1.33 & 574 & 3.41 \\
\hline Georgia & 413 & 1.12 & 78 & 0.46 \\
\hline Iraq & $2^{\prime} 212$ & 6.02 & 703 & 4.18 \\
\hline Iran & $1^{\prime} 048$ & 2.85 & 535 & 3.18 \\
\hline Kosovo & 544 & 1.48 & 482 & 2.86 \\
\hline Latin America & 83 & 0.23 & 67 & 0.40 \\
\hline Macedonia & 233 & 0.63 & 237 & 1.41 \\
\hline Mongolia & 55 & 0.15 & 96 & 0.57 \\
\hline Nigeria & $1^{\prime} 804$ & 4.91 & 257 & 1.53 \\
\hline Other Africa & $4^{\prime} 214$ & 11.47 & 490 & 2.91 \\
\hline Other Asia/Oceania & 456 & 1.24 & 188 & 1.12 \\
\hline Other Europe & 261 & 0.71 & 167 & 0.99 \\
\hline Pakistan & 293 & 0.80 & 55 & 0.33 \\
\hline Russia & 321 & 0.87 & 299 & 1.78 \\
\hline Serbia & 815 & 2.22 & 864 & 5.13 \\
\hline Somalia & $2^{\prime} 272$ & 6.19 & 840 & 4.99 \\
\hline Sri Lanka & $2^{\prime} 804$ & 7.63 & $1^{\prime} 033$ & 6.14 \\
\hline Syria & $1^{\prime} 967$ & 5.36 & 925 & 5.50 \\
\hline Togo & 335 & 0.91 & 137 & 0.81 \\
\hline Tunisia & $1^{\prime} 614$ & 4.39 & 68 & 0.40 \\
\hline Turkey & $1^{\prime} 928$ & 5.25 & $1^{\prime} 025$ & 6.09 \\
\hline Yemen & 105 & 0.29 & 64 & 0.38 \\
\hline Unknown/Stateless & 553 & 1.51 & 137 & 0.81 \\
\hline Total & $36^{\prime} 730$ & 100 & $16^{\prime} 832$ & 100 \\
\hline
\end{tabular}


Appendix 2: Longitudinal follow-up, individuals' trajectories according to their residence permit (or status) by sex, 2000-2013 arrival cohorts

Men (68.6\%)

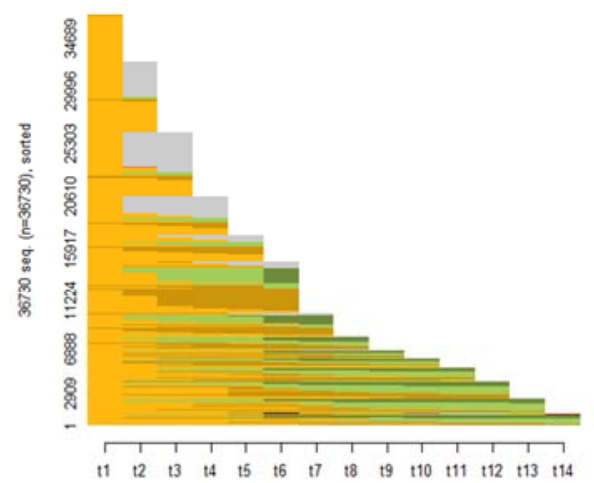

Women $(31.4 \%)$

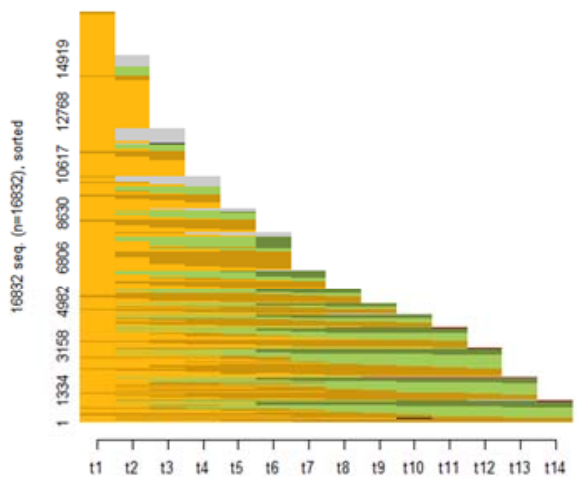

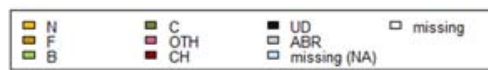

Note: In these figures there is a difference between the state «missing information (NA)» represented in blue and the state «missing» in white that corresponds here to the end of the observation period (which is linked to the cohort of arrival).

Data source: The «Refugee database». 


\section{Appendix 3: Explanatory factors of the occurrence of the event «first integration into the labour market", discrete time survival models - odds ratios, 2000-2013 arrival cohorts}

\begin{tabular}{|c|c|c|}
\hline & \multirow[b]{2}{*}{ Men } & \multirow[b]{2}{*}{ Women } \\
\hline & & \\
\hline \multicolumn{3}{|l|}{ Residence permit (ref. = N) } \\
\hline $\mathrm{F}$ & $1.481 * * *$ & 0.930 \\
\hline B & $1.630 * * *$ & $2.019 * * *$ \\
\hline $\mathrm{C}$ & $1.858 * * *$ & $1.403^{* *}$ \\
\hline $\mathrm{CH}$ & 1.579 & 1.720 \\
\hline OTH/UD/missing & 0.566 & 2.222 \\
\hline \multicolumn{3}{|l|}{ Length of stay (in years) } \\
\hline 1 & $0.002 * * *$ & $0.002 * * *$ \\
\hline 2 & $0.291 * * *$ & $0.175^{* * *}$ \\
\hline 3 & $0.826 * * *$ & $0.794^{*}$ \\
\hline 4 & $0.858 * * *$ & 1.038 \\
\hline 5 (reference) & 1 & 1 \\
\hline 6 & $1.101^{*}$ & $1.390 * *$ \\
\hline 7 & $1.268 * * *$ & $1.726 * * *$ \\
\hline 8 & $1.339 * * *$ & $2.154 * * *$ \\
\hline 9 & $1.294^{* * *}$ & $1.856 * * *$ \\
\hline 10 & 0.939 & $1.652 * * *$ \\
\hline 11 & 0.913 & $1.763 * * *$ \\
\hline 12 & 0.916 & $1.469 * *$ \\
\hline 13 & $0.671^{*}$ & $1.497^{*}$ \\
\hline 14 & 0.980 & 1.357 \\
\hline Age (in years) & $1.107 * * *$ & 1.020 \\
\hline $\mathrm{Age}^{2} / 100$ & $0.811^{* * *}$ & $0.945^{\circ}$ \\
\hline \multicolumn{3}{|l|}{ Marital status (ref. = not married) } \\
\hline Married & $1.147^{* * *}$ & $0.670 * * *$ \\
\hline Unknown & $0.122 * * *$ & $0.122^{* * *}$ \\
\hline \multicolumn{3}{|l|}{ Nationality (ref. = Eritrea) } \\
\hline Afghanistan & $2.322 * * *$ & 1.021 \\
\hline Algeria & $1.428^{*}$ & 0.857 \\
\hline Angola & $3.078 * * *$ & $2.075^{* * *}$ \\
\hline Armenia & $1.557^{\circ}$ & $5.111 * * *$ \\
\hline Bosnia and Herzegovina & $1.884^{* * *}$ & $3.727^{* * *}$ \\
\hline Cameroon & $2.443 * * *$ & $2.276 * * *$ \\
\hline China and Tibet & $3.701 * * *$ & $10.902 * * *$ \\
\hline Côte d'Ivoire & $1.858^{* * *}$ & $3.143^{* * *}$ \\
\hline Democratic Republic of Congo & $2.495^{* * *}$ & $2.750 * * *$ \\
\hline Ethiopia & $2.233^{* * *}$ & $3.865 * * *$ \\
\hline Georgia & $0.418^{*}$ & $2.485^{*}$ \\
\hline Iraq & $2.138 * * *$ & 1.268 \\
\hline Iran & $1.238 * *$ & $2.791 * * *$ \\
\hline Kosovo & $1.908 * * *$ & $1.967^{* * *}$ \\
\hline Latin America & $1.546^{\circ}$ & $2.644 * *$ \\
\hline Macedonia & $1.995 * * *$ & $2.827^{* * *}$ \\
\hline
\end{tabular}




\begin{tabular}{|c|c|c|}
\hline Mongolia & 1.566 & $2.687^{*}$ \\
\hline Nigeria & $0.699^{\circ}$ & $2.209^{\circ}$ \\
\hline Other Africa & $1.377^{* * *}$ & $2.724 * * *$ \\
\hline Other Asia/Oceania & $2.122^{* * *}$ & $3.378 * * *$ \\
\hline Other Europe & $1.893 * * *$ & $3.319 * * *$ \\
\hline Pakistan & $3.105^{* * *}$ & 1.766 \\
\hline Russia & 1.083 & $2.190 * * *$ \\
\hline Serbia & $1.713^{* * *}$ & $2.275^{* * *}$ \\
\hline Somalia & $1.193^{* * *}$ & 1.062 \\
\hline Sri Lanka & $5.041 * * *$ & $2.574 * * *$ \\
\hline Syria & 1.122 & $0.363 * *$ \\
\hline Togo & $3.142^{* * *}$ & $2.978 * * *$ \\
\hline Tunisia & 0.899 & 1.159 \\
\hline Turkey & $1.240 * * *$ & $2.018 * * *$ \\
\hline Yemen & 0.757 & 0.198 \\
\hline Unknown/Stateless & 0.838 & 0.929 \\
\hline \multicolumn{3}{|l|}{ Canton of residence (ref. $=\mathrm{ZH}$ ) } \\
\hline $\mathrm{BE}$ & $0.532 * * *$ & $0.592 * * *$ \\
\hline LU & 0.999 & $0.816^{\circ}$ \\
\hline UR & $0.719 *$ & $0.422^{\circ}$ \\
\hline SZ & $1.266 * *$ & 0.997 \\
\hline OW & 0.823 & 1.428 \\
\hline NW & $0.592 * *$ & $0.111^{*}$ \\
\hline $\mathrm{GL}$ & 0.878 & 1.230 \\
\hline ZG & 0.896 & 0.973 \\
\hline $\mathrm{FR}$ & 0.947 & 0.882 \\
\hline SO & $0.826 * *$ & $0.541 * * *$ \\
\hline BS & $0.666^{* * *}$ & 0.756 \\
\hline $\mathrm{BL}$ & $0.888^{\circ}$ & 1.042 \\
\hline $\mathrm{SH}$ & 0.989 & 0.869 \\
\hline$A R$ & $0.713^{* *}$ & 1.226 \\
\hline $\mathrm{Al}$ & $0.651^{\circ}$ & $5.264 * * *$ \\
\hline SG & 1.082 & 0.893 \\
\hline GR & $2.010^{* * *}$ & $1.837 * * *$ \\
\hline$A G$ & $0.733 * * *$ & $0.775^{*}$ \\
\hline TG & 0.877 & $0.597^{*}$ \\
\hline $\mathrm{TI}$ & $0.577^{* * *}$ & $0.265 * * *$ \\
\hline VD & $0.878 * *$ & 0.898 \\
\hline VS & $0.832^{*}$ & 0.829 \\
\hline NE & $0.794 * *$ & 1.163 \\
\hline GE & 0.960 & 1.028 \\
\hline JU & $0.454 * * *$ & 0.631 \\
\hline Unknown & $1.477^{* * *}$ & $1.484 * *$ \\
\hline Constant & $0.024 * * *$ & $0.013 * * *$ \\
\hline Observations (person-year) & $132^{\prime} 742$ & $89^{\prime} 145$ \\
\hline Log Likelihood & $-27^{\prime} 888.8$ & $-8^{\prime} 276.3$ \\
\hline Akaike Inf. Crit. & $55^{\prime} 939.7$ & $16^{\prime} 714.6$ \\
\hline
\end{tabular}

Statistical significance: ${ }^{\circ} p<0.1{ }^{*} p<0.05 ; * * p<0.01 ; * * * p<0.001$.

Data source: The «Refugee database». 